\title{
Geochemical characteristics, thermal maturity and source rock potential of the Oligocene Šitbořice Member of the Menilite Formation in the Ždánice Unit (Czech Republic)
}

\author{
Petr JIRMAN ${ }^{1,3}$ *, Eva GERŠLOVÁ ${ }^{1}$, Magdalena PUPP ${ }^{2}$ and Miroslav BUBíK ${ }^{3}$ \\ 1 Masaryk University, Faculty of Science, Department of Geological Sciences, Kotlářská 2, 61137 Brno, Czech Republic \\ 2 Montanuniversität Leoben, Chair of Petroleum Geology, Peter-Tunner Straße 5, 8700 Leoben, Austria \\ 3 Czech Geological Survey, Leitnerova 22, 60200 Brno, Czech Republic
}

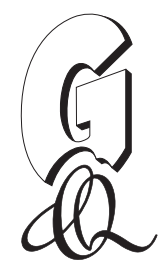

Jirman, P., Geršlová, E., Pupp, M., Bubík, M., 2018. Geochemical characteristics, thermal maturity and source rock potential of the Oligocene Šitbořice Member of the Menilite Formation in the Ždánice Unit (Czech Republic). Geological Quarterly, 62 (4): 00-00, doi: 10.7306/gq.1447

Associate editor: Dariusz Więcław

Rocks deposited in the Oligocene Paratethys are recognized as one of the most important source rocks in the Flysch Carpathians. The Šitbořice Member (uppermost NP23 to lowermost NP25 zone) represents the upper part of the Menilite Formation in the Outer Flysch Carpathians of the Czech Republic. This paper presents results of bulk geochemical analysis, Rock-Eval pyrolysis and organic petrography. The geochemical evaluation, source rock potential, kerogen type and thermal maturity were studied using borehole cores. Based on the classification of Peters (1986), the evaluated Šitborice Member is mostly classified as a "very good" source rock according to TOC and variable, mostly "poor" to "good" according to the petroleum potential. However, the average petroleum potential value assigned the member to "good" source rock which is in accordance with the TOC classification if the "live" TOC is used. A comparable distribution between kerogen type II and III has been indicated by HI. Unlike this, the organic petrography observations show the organic matter belongs to the kerogen type II which corresponds to the relationship of residual hydrocarbon potential versus TOC and HI calculated based on "live" organic carbon. Presumed immaturity was confirmed by $R_{r}$ and Rock-Eval $T_{\max }$. Oxygen-restricted conditions or a dysoxic environment have been indicated by the TOC/TS ratio.

Key words: Šitboriice Member, Menilite Formation, Outer Flysch Carpathians, source rock potential, thermal maturity, organic petrography.

\section{INTRODUCTION}

The bituminous Menilite Formation was first described by Glocker (1844) in the Moravia region and referred to as "rocks with menilite". Menilite is a layered greyish-brown form of the opal first reported from Ménilmontant in Paris, France. Its origin may be explained by diagenesis of diatomites. Nowadays, the Menilite Formation is regarded as one of the most prolific hydrocarbon source rocks of the Outer Flysch Carpathians. Systematic research on the Menilite Formation (or its equivalents) in Austria, Poland and Ukraine has brought detailed characterization of the depositional environment, organic matter genetic type, petroleum potential and thermal maturity (e.g., Koltun, 1992; Schmidt and Erdogan, 1996; Köster et al., 1998a, b; Schulz et al., 2002, 2004; Curtis et al., 2004; Kotarba et al.,

\footnotetext{
* Corresponding author, e-mail: p.jirman@seznam.cz Received: March 23, 2018; accepted: July 16, 2018; first published online: December 18, 2018
}

2005, 2007, 2013, 2014, 2017; Lewan et al., 2006; Sachsenhofer and Schulz, 2006; Kosakowski et al., 2009, 2018; Sachsenhofer et al., 2010; Gusterhuber et al., 2013; Kosakowski, 2013; Ziemianin et al., 2015). Accordingly, the main aim of this study is to fill the gap and evaluate the source rock potential, kerogen type and thermal maturity of the Šitborice Member of the Menilite Formation in the Ždánice Unit (Outer Flysch Carpathians, Czech Republic).

\section{GEOLOGICAL SETTINGS}

The Western Carpathian Flysch Belt on the territory of the Czech Republic (Fig. 1) forms a SW-NE trending segment of the Carpathians. It is subdivided into two groups - the Krosno-Menilite Group of Nappes (also known as the external group) and the Magura Group of Nappes (also known as the internal one, Chlupáč et al., 2002). The Krosno-Menilite Group of Nappes is characterized by successions of variegated shales of Late Cretaceous to Late Eocene age, menilitic silicites of Early 

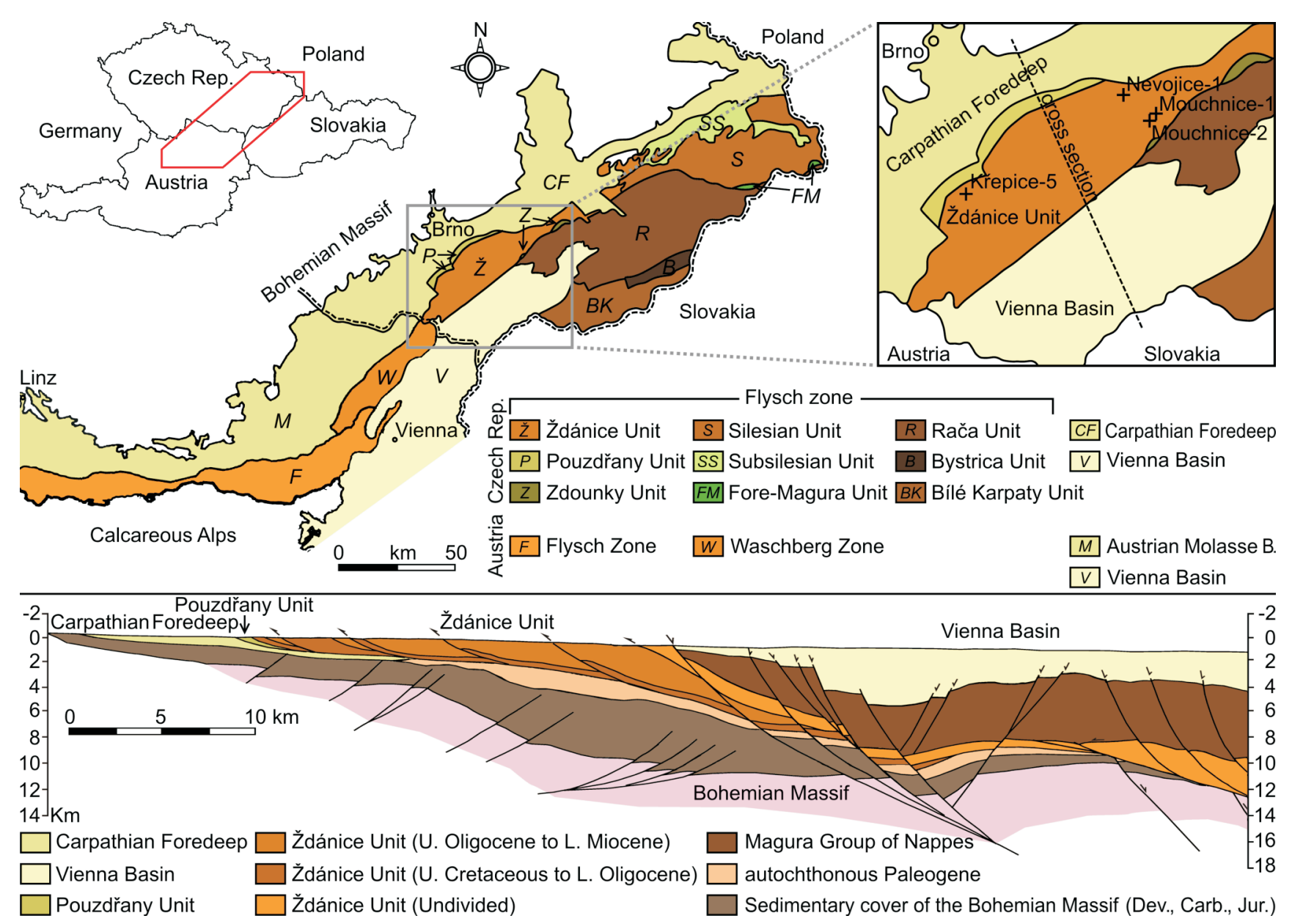

Fig. 1. Schematic geological map with position of the selected boreholes Mouchnice-1, Mouchnice-2 and Nevojice-1

The position of the Křepice-5 borehole from which a detailed stratigraphic description of the Menilite Formation originates is added; the cross-section is according to Pícha et al. (2006)

Oligocene age and Krosno-type flysch of the Late Oligocene to Early Miocene age (Pícha et al., 2006).

The Krosno-Menilite Group of Nappes comprises the Pouzdřany, Ždánice, Zdounky, Silesian, Subsilesian and Fore-Magura units (Chlupáč et al., 2002). The stratigraphic range of these units extends from the Jurassic to the Lower Miocene. However, most of them encompass the Upper Cretaceous to Lower Miocene interval.

The entire Carpathian Flysch Belt was thrust north-westwards onto the autochthonous Miocene strata of the Carpathian Foredeep and eastern slope (margin) of the Bohemian Massif (Pícha et al., 2006).

\section{ŽDÁNICE UNIT}

This tectonic unit forms a part of the external zone of the Outer Flysch Carpathians. The continuation of this unit in the Austrian territory is named the Waschberg Zone (Fuchs et al., 2001; Rögl et al., 2001; Fig. 1). The Ždánice Unit comprises strata of the Upper Cretaceous (Campanian-Maastrichtian) to the Lower Miocene (Egerian to Karpatian). The unit is subdivided into the following formations (Chlupáč et al., 2002):
- the Němčice Formation (including the Sheshory Marls),

- the Menilite Formation (including the Subchert and Chert members, Dynow Marlstone and Šitbořice Member),

- the Ždánice-Hustopeče Formation,

- the Šakvice Marls,

- the Pavlovice Formation,

- the Laa Formation.

The continuous sequence of the Western Carpathian Flysch Belt is represented by the Němčice Formation of Late Cretaceous to Early Oligocene age, the Menilite Formation of Early to Late Oligocene age and the Ždánice-Hustopeče Formation of Late Oligocene to Early Miocene (Egerian) age. The Šakvice Marls, Pavlovice and Laa formations represent Egerian to Karpatian age molasse-type sediments of the piggy-back type basin formed on the folded Ždánice Nappe.

\section{MENILITE FORMATION}

The Menilite Formation is subdivided into the Subchert Member, Chert Member (also known as menilitic cherts), Dynow Marlstone and Šitbořice Member (Stráník et al., 1974; Stráník, 1981). 
The Subchert Member gradually passes up from the Sheshory Marls and is formed of brown stratified marls interbedded with dark laminated shales with fish scales (Pícha et al., 2006). The member represents strata deposited during stepwise isolation from the world ocean (Švábenická et al., 2007). The Subchert Member passes upwards into organic-rich laminated cherts and non-calcareous siliceous shales of the Chert Member. The Chert Member was deposited in bathyal, anoxic conditions with limited influx of detrital material (Pícha and Stráník, 1999). The origin of the cherts may be explained by prolonged deposition of diatomites related to low salinity, cooling of climate and increased seasonality (Krhovský, 1981). A water depth from 200 to $1000 \mathrm{~m}$ of the depositional environment for the Chert Member was suggested by Brzobohatý (1981) and Gregorová (1988). The Dynow Marlstone composed of nannofossil pelagic limestones and marlstones overlies the Chert Member. During its deposition anoxic conditions still affected the deep water environment. Slightly increased surface salinity enabled a mass development of calcareous nannofossils, but it did not reach the normal values required to enable the return of planktonic foraminifers (Krhovský, 1981). The argillaceous sequence of the Šitbořice Member represents the terminal part of the Menilite Formation (Stráník, 1981). The base of the Šitborice Member is commonly formed of slumps and debris flows with an erosional base (Stráník, 1981) related to the Šitbořice Event of Krhovský and Djurasinović (1993). The characteristic section of this member is formed of brown non-calcareous shales, occasionally with bodies of mudstone in the lower part, to green and brown shales with carbonate concretions in the upper part (Stráník et al., 1981). The Šitbořice Member reflects the restoration of normal marine salinity. Anoxic conditions alternated with oxic episodes is as apparent from horizons with articulated fish skeletons. The total thickness of the Menilite Formation in the Ždánice Unit does not exceed $200 \mathrm{~m}$. The Menilite Formation in the Ždánice Unit was assigned to the Lower Oligocene (Krhovský et al., 1992). However, earlier studies admit also the Eocene-Oligocene transition boundary (Stráník and Hanzlíková, 1968). The stratigraphic cutting out of the Ždánice Unit is shown on Figure 2 with brief comparison to analogous units of the Austrian Molasse Basin and Waschberg Zone. The Eocene-Oligocene boundary represents a critical change from a greenhouse climate into the ice-house conditions associated with the major extinction in the Early Oligocene (Prothero et al., 2000) and overall ocean fertility increase (Baldauf and Barron, 1990; Salamy and Zachos, 1999; Thomas et al., 2000) as a prerequisite of hydrocarbon development.

\section{COMPARISON WITH STRATIGRAPHIC ANALOGUES IN AUSTRIA, POLAND AND UKRAINE}

The Eggerding and Zupfing formations within the Austrian Molasse Basin and the Thomasl Formation in the Waschberg Zone are regarded as stratigraphic analogues of the Šitbořice Member (Wagner, 1996, 1998; Krhovský et al., 2001).

The lithology of the Eggerding Formation is dominated by grey laminated pelites with laminae of white nannofossil limestone/nannochalk (Sachsenhofer et al., 2010). The thickness of the formation ranges from $\sim 35$ to $\sim 50 \mathrm{~m}$. The overlaying Zupfing Formation is composed of dark grey hemipelagites, distal turbidities, and slump and slide bodies (Sachsenhofer et al., 2010). This formation is up to $450 \mathrm{~m}$ thick. The lithology of the Thomasl Formation is composed of dark variegated shales with calcareous and marly layers and sandy or silty intercalations (Rögl et al., 2001).

Based on the terminology of Peters (1986), Sachsenhofer et al. (2010) evaluated the lower part of the Eggerding Formation as a "very good" source rock for oil and the upper part as a "good" oil-prone source rock. Both the Eggerding and the lower part of the Zupfing formations are considered to be minor source rocks (Schulz et al., 2002; Sachsenhofer et al., 2010). According to Pupp et al. (2018), the Thomasl Formation encountered in the Poysdorf and Thomasl wells holds a "fair" to "good" source rock potential which is in contrast with the "poor" potential of the same formation of the Ottenthal section.

Kerogen type II and III within the lower part of the Eggerding Formation (Schulz et al., 2004; Sachsenhofer et al., 2010) and predominantly of type III within the rest of the Eggerding (Schmidt and Erdogan, 1996) and Thomasl formations (Pupp et al., 2018) are indicated by Rock-Eval hydrogen index (HI) values. The prevailing immaturity was supported by vitrinite reflectance $\left(R_{r}\right)$ measurements and Rock-Eval $T_{\max }$ values in all of

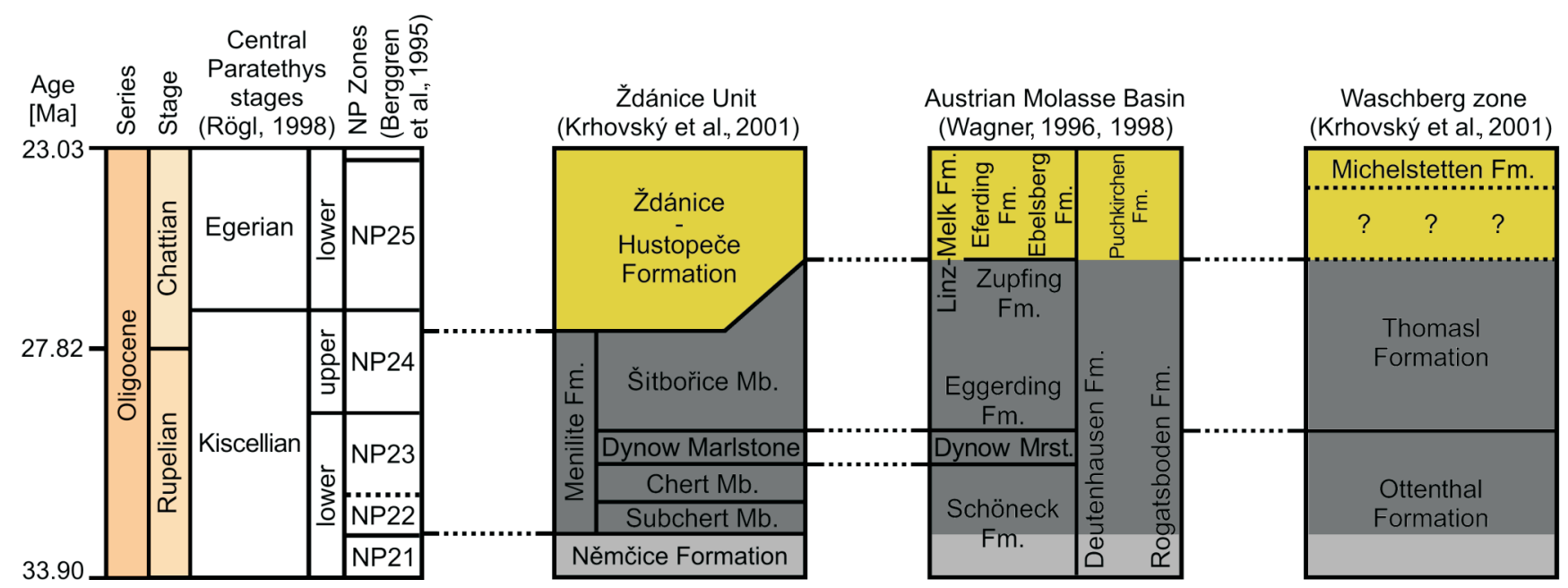

Fig. 2. Oligocene stratigraphic correlation of the Ždánice Unit, Austrian Molasse Basin and Waschberg Zone

Modified according to Krhovský et al. (2001) for Czech territory and according to Wagner $(1996,1998)$ for Austrian territory; stages of the Central Paratethys are according to Rögl (1998); NP Zones are according to Berggren et al. (1995) 
the Eggerding, Zupfing and Thomasl formations (Sachsenhofer et al., 2010; Pupp et al., 2018).

Oxygen-restricted conditions were indicated by the TOC/TS ratio in the Eggerding and Zupfing formations (Sachsenhofer et al., 2010) and supported by biomarkers in the Thomasl Formation within the Ottenthal section (Pupp et al., 2018). Strongly oxygen-depleted conditions were indicated by biomarkers in the same formation in the Thomasl well (Pupp et al., 2018).

Several comprehensive studies have been published from the Polish and Ukrainian Carpathians. The Menilite Shales are known in the area of Poland from the Skole, Subsilesian, Silesian and Dukla units and strata occurring in tectonic windows of the Magura Unit. In the area of Ukraine, the Menilite Shales are known from the Boryslav-Pokuttya, Skyba (Skole), Krosno (Silesian), Chornogora and Dukla units. Most of the studies are focused on the Boryslav-Pokuttya, Skole, Silesian and Dukla units.

The source rock potential is variable, mostly very good to moderate (Kotarba and Koltun, 2006; Kotarba et al., 2013, 2014). Good to excellent petroleum potential has been observed in the Skole (Skyba) and Boryslav-Pokuttya units (Kosakowski et al., 2009; Sachsenhofer and Koltun, 2012). Locally, the TOC exceeds 20 wt.\% (e.g., ten Haven et al., 1993; Kruge et al., 1996; Köster et al., 1998a, b; Kotarba et al., 2007; Kosakowski et al., 2009) but normally ranges between 4 and 8 wt.\% (Sachsenhofer and Koltun, 2012; Kosakowski, 2013; Kosakowski et al., 2018).

Oil-prone kerogen type II prevails in all the Boryslav-Pokuttya, Skole (Skyba), Silesian (Krosno) and Dukla units (Koltun et al., 1998; Sachsenhofer and Koltun, 2012; Kosakowski, 2013; Kotarba et al., 2013, 2014, 2017). Admixtures of kerogen type I and II/III or III are present in the Boryslav-Pokuttya, Skole (Skyba), Silesian (Krosno) and Dukla units (Kosakowski, 2013; Kotarba et al., 2013, 2014, 2017). Admixtures of kerogen type I and significant admixtures of kerogen type III have been observed within the Skole (Skyba) Unit
(Kosakowski, 2013). The composition of kerogen type II-III was also indicated in the Ukrainian part of the Krosno (Silesian) Unit by Sachsenhofer and Koltun (2012).

The $T_{\max }$ temperature indicates the bottom of the "oil window" in the Boryslav-Pokuttya Unit and immaturity or an initial stage of low-temperature thermogenic process in the Skole (Skyba) Unit (Koltun et al., 1998; Kotarba et al., 2007, 2014; Kosakowski, 2013). The initial to final stage of low-temperature thermogenic process in the Silesian (Krosno) Unit and initial to main stages of the "oil window" and locally even overmaturity in the Dukla Unit have been observed by Kosakowski (2013) and Kotarba et al. (2013, 2014, 2017), respectively. In general, an increasing trend of maturity towards the internal units has been observed (e.g., Kruge et al., 1996; Köster et al., 1998a, b; Kotarba and Koltun, 2006; Sachsenhofer and Koltun, 2012).

\section{SAMPLES AND METHODS}

Four core intervals from 3 boreholes representing the Šitborice Member were studied (Fig. 3). All three boreholes penetrated the Ždánice Nappe and reached autochthonous units (crystalline basement overlain by Miocene strata of the Carpathian Foredeep). In the Ždánice Nappe the Němčice, Menilite and Ždánice-Hustopeče formations were encountered (Fig. 3).

Two borehole cores came from the Mouchnice-1 borehole (Core $\mathrm{No}^{\circ} 6$ from the depth of 997.5 to $1002 \mathrm{~m}$ and Core $\mathrm{No}^{\circ} 7$ from 1050.5 to $1055 \mathrm{~m}$, respectively), one from the Mouchnice-2 borehole (depth of 1040 to $1043.9 \mathrm{~m}$ ) and one from the Nevojice-1 borehole (depth of 500 to $503 \mathrm{~m}$ ). Each core was lithologically described and sampled in order to record detailed changes and to cover the whole sequence of cored intervals (Table 1). The samples were ground and total organic matter, total sulphur and free and residual hydrocarbons were determined. Samples of up to $80 \mathrm{mg}$ were used for each measuring round.

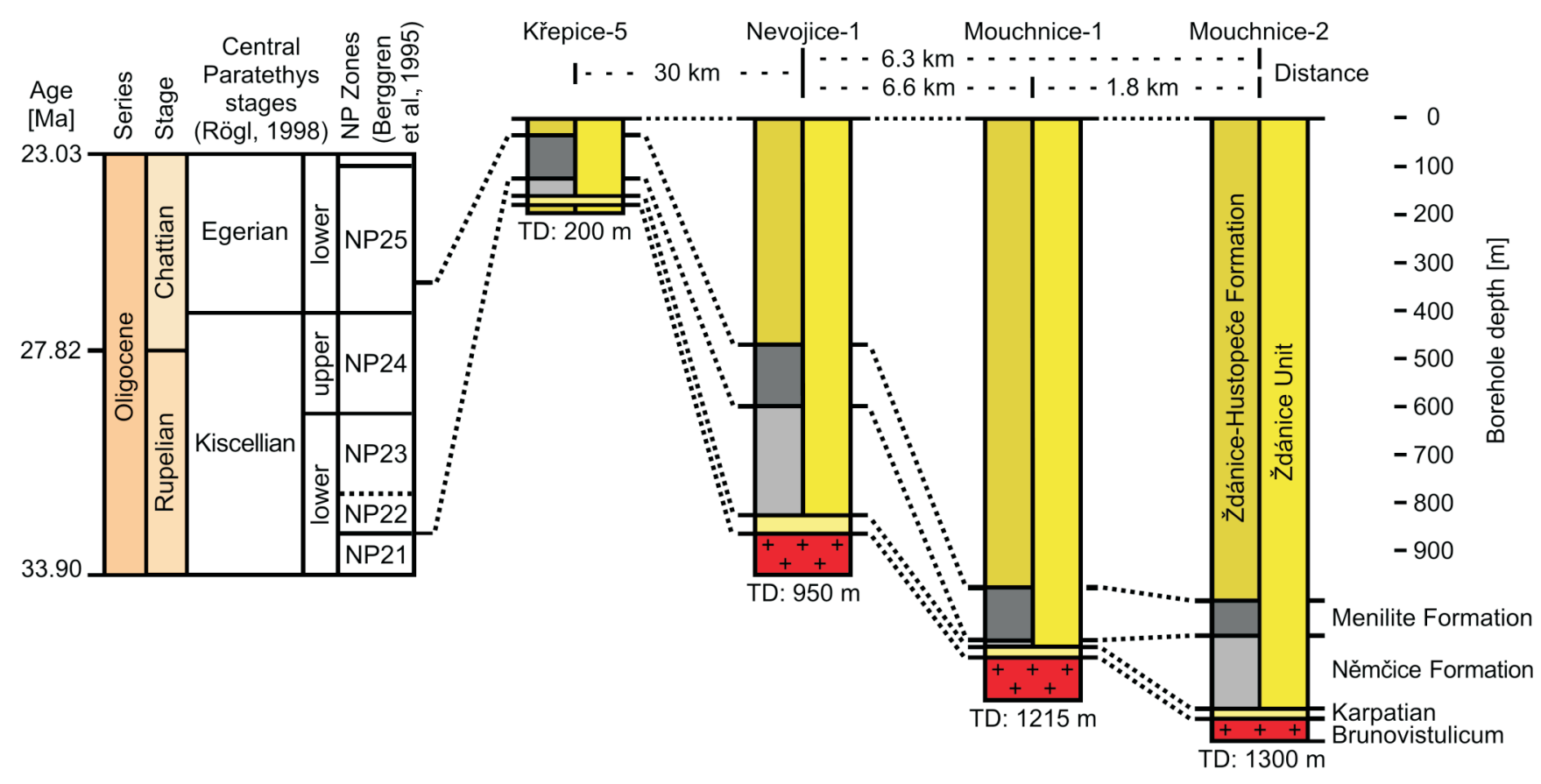

Fig. 3. Borehole profiles comparison

Modified according to Stráník (1979) for Křepice-5, Krejčí et al. (1989) for Nevojice-1, Dohnal et al. (1987) for Mouchnice-1 and Krejčí et al. (1991) for Mouchnice-2; stages of Central Paratethys are according to Rögl (1998); NP Zones are according to Berggren et al. (1995) 
Characteristics of the organic matter from the Šitbořice Member in the area of the Ždánice Unit in the SE part of the Czech Republic

\begin{tabular}{|c|c|c|c|c|c|c|c|c|c|c|c|c|c|}
\hline \multirow{3}{*}{ Borehole } & \multirow{3}{*}{$\begin{array}{c}\text { Depth } \\
\text { [m] }\end{array}$} & \multicolumn{6}{|c|}{ Rock-Eval data } & \multicolumn{6}{|c|}{ Bulk geochemical data } \\
\hline & & $\mathrm{S}_{1}$ & $\mathrm{~S}_{2}$ & $S_{1}+S_{2}$ & \multirow{2}{*}{$\begin{array}{l}\mathrm{T}_{\max } \\
{\left[{ }^{\circ} \mathrm{C}\right]}\end{array}$} & \multirow{2}{*}{$\begin{array}{c}\mathrm{HI} \\
{[\mathrm{mg} \mathrm{HC} / \mathrm{g} \mathrm{TOC}]}\end{array}$} & \multirow[t]{2}{*}{$\mathrm{PI}$} & TOC & TS & TOC/TS & TIC & Calc. Eq. & $R_{r}$ \\
\hline & & \multicolumn{3}{|c|}{ [mg HC/g] } & & & & [wt.\%] & [wt.\%] & & [wt.\%] & [wt.\%] & {$[\%]$} \\
\hline \multirow{11}{*}{$\begin{array}{l}\text { Mouchnice-1 } \\
\left(\text { Core } \mathrm{No}^{\circ} 6\right)\end{array}$} & 997.5 & 0.1 & 2.6 & 2.7 & 423 & 150 & 0.02 & 1.7 & 3.1 & 0.56 & 0.2 & 2.0 & - \\
\hline & 997.9 & 0.1 & 4.3 & 4.4 & 414 & 151 & 0.02 & 2.8 & 3.1 & 0.91 & 0.4 & 3.1 & 0.24 \\
\hline & 998.5 & 0.0 & 0.6 & 0.6 & 422 & 81 & 0.03 & 0.8 & 2.9 & 0.26 & 0.2 & 1.8 & - \\
\hline & 999.0 & 0.1 & 2.4 & 2.5 & 410 & 90 & 0.03 & 2.7 & 3.2 & 0.83 & 0.0 & 0.0 & 0.28 \\
\hline & 999.1 & 0.0 & 0.8 & 0.8 & 412 & 55 & 0.05 & 1.4 & 2.5 & 0.56 & 0.0 & 0.4 & - \\
\hline & 999.5 & 0.0 & 0.6 & 0.7 & 417 & 65 & 0.05 & 1.0 & 2.1 & 0.47 & 0.1 & 0.7 & - \\
\hline & 999.8 & 0.0 & 1.0 & 1.1 & 421 & 98 & 0.03 & 1.1 & 2.6 & 0.41 & 0.5 & 4.1 & - \\
\hline & 1000.5 & 0.0 & 1.2 & 1.3 & 422 & 100 & 0.03 & 1.2 & 3.3 & 0.37 & 0.3 & 2.5 & - \\
\hline & 1000.9 & 0.1 & 1.6 & 1.7 & 420 & 104 & 0.03 & 1.6 & 2.2 & 0.70 & 0.3 & 2.1 & - \\
\hline & 1001.0 & 0.0 & 0.8 & 0.9 & 413 & 58 & 0.05 & 1.4 & 2.1 & 0.65 & 0.0 & 0.3 & - \\
\hline & 1002.0 & 0.0 & 1.6 & 1.7 & 424 & 121 & 0.03 & 1.3 & 2.6 & 0.52 & 0.8 & 6.4 & - \\
\hline \multirow{11}{*}{$\begin{array}{l}\text { Mouchnice-1 } \\
\left(\text { Core } \mathrm{No}^{\circ} 7\right)\end{array}$} & 1050.5 & 0.1 & 1.5 & 1.6 & 411 & 72 & 0.05 & 2.1 & 2.9 & 0.73 & 0.0 & 0.1 & - \\
\hline & 1050.95 & 0.2 & 5.3 & 5.4 & 410 & 136 & 0.03 & 3.9 & 3.1 & 1.24 & 0.2 & 1.7 & - \\
\hline & 1051.5 & 0.2 & 8.5 & 8.6 & 421 & 247 & 0.02 & 3.4 & 3.4 & 1.02 & 2.9 & 24.0 & - \\
\hline & 1051.9 & 0.7 & 23.7 & 24.4 & 407 & 346 & 0.03 & 6.9 & 4.4 & 1.55 & 1.9 & 15.8 & - \\
\hline & 1052.0 & 0.2 & 7.4 & 7.6 & 409 & 166 & 0.02 & 4.5 & 3.1 & 1.44 & 0.0 & 0.0 & - \\
\hline & 1052.3 & 0.2 & 7.1 & 7.3 & 412 & 188 & 0.02 & 3.8 & 3.8 & 1.00 & 0.6 & 4.6 & - \\
\hline & 1052.8 & 0.1 & 4.9 & 5.1 & 413 & 163 & 0.03 & 3.0 & 3.0 & 1.00 & 0.7 & 5.5 & - \\
\hline & 1053.5 & 0.2 & 7.7 & 7.9 & 406 & 184 & 0.03 & 4.2 & 3.2 & 1.31 & 0.0 & 0.1 & - \\
\hline & 1053.9 & 0.2 & 6.4 & 6.5 & 405 & 213 & 0.03 & 3.0 & 2.6 & 1.16 & 0.1 & 0.6 & - \\
\hline & 1054.0 & 0.5 & 26.5 & 27.0 & 416 & 541 & 0.02 & 4.9 & 2.5 & 1.95 & 6.2 & 52.1 & - \\
\hline & 1055.0 & 0.3 & 9.3 & 9.6 & 410 & 232 & 0.03 & 4.0 & 3.2 & 1.25 & 1.7 & 14.5 & - \\
\hline \multirow{11}{*}{ Mouchnice-2 } & 1040 & 0.0 & 0.3 & 0.4 & 413 & 53 & 0.06 & 0.6 & 2.7 & 0.23 & 1.0 & 8.3 & - \\
\hline & 1040.5 & 0.1 & 4.6 & 4.7 & 411 & 202 & 0.02 & 2.3 & 3.6 & 0.64 & 0.3 & 2.8 & - \\
\hline & 1040.9 & 0.1 & 5.7 & 5.9 & 416 & 249 & 0.02 & 2.3 & 3.2 & 0.73 & 1.2 & 9.7 & - \\
\hline & 1041.1 & 0.1 & 2.9 & 3.0 & 410 & 131 & 0.03 & 2.2 & 2.8 & 0.79 & 0.1 & 0.7 & - \\
\hline & 1041.9 & 0.5 & 26.4 & 26.9 & 413 & 535 & 0.02 & 4.9 & 3.9 & 1.27 & 0.4 & 3.4 & - \\
\hline & 1042.1 & 0.1 & 3.2 & 3.3 & 412 & 153 & 0.03 & 2.1 & 2.7 & 0.80 & 0.3 & 2.4 & - \\
\hline & 1042.5 & 0.8 & 26.9 & 27.7 & 403 & 406 & 0.03 & 6.6 & 4.0 & 1.64 & 0.0 & 0.1 & - \\
\hline & 1042.9 & 0.3 & 14.4 & 14.8 & 410 & 384 & 0.02 & 3.8 & 3.4 & 1.09 & 0.3 & 2.4 & - \\
\hline & 1043.2 & 0.4 & 20.5 & 20.9 & 410 & 468 & 0.02 & 4.4 & 3.5 & 1.23 & 0.8 & 6.9 & 0.26 \\
\hline & 1043.5 & 0.3 & 9.3 & 9.6 & 403 & 249 & 0.03 & 3.7 & 3.3 & 1.14 & 0.1 & 0.7 & - \\
\hline & 1043.9 & 0.4 & 11.9 & 12.2 & 409 & 322 & 0.03 & 3.7 & 4.0 & 0.92 & 0.2 & 1.7 & - \\
\hline \multirow{4}{*}{ Nevojice-1 } & 500 & 0.0 & 1.1 & 1.2 & 414 & 85 & 0.03 & 1.3 & 2.4 & 0.54 & 0.1 & 1.0 & - \\
\hline & 501 & 0.1 & 3.6 & 3.8 & 404 & 126 & 0.04 & 2.9 & 2.3 & 1.23 & 0.1 & 0.9 & 0.31 \\
\hline & 502 & 0.1 & 2.0 & 2.1 & 400 & 80 & 0.06 & 2.5 & 2.9 & 0.86 & 0.0 & 0.0 & - \\
\hline & 503 & 0.2 & 7.7 & 8.0 & 401 & 238 & 0.03 & 3.2 & 2.1 & 1.53 & 0.0 & 0.0 & - \\
\hline
\end{tabular}

$\mathrm{S}_{1}$ - free hydrocarbons content; $\mathrm{S}_{2}$ - residual hydrocarbon potential; $\mathrm{S}_{1}+\mathrm{S}_{2}$ - petroleum potential; $T_{\max }-$ temperature of maximum of $\mathrm{S}_{2}$ peak; $\mathrm{HI}$ - hydrogen index; PI - production index; TOC - total organic carbon; TS - total sulphur content; TIC - total inorganic carbon; Calc. Eq. calcite equivalent; $R_{r}-$ random vitrinite reflectance 
The borehole correlations and stratigraphical reconstruction of the cored intervals within the Menilite Formation were done based on borehole gamma logging records (Hrubanová and Těžký, 1980; Šelle, 1987, 1988; Kowalska et al., 1988).

Contents of total carbon (TC), total organic carbon (TOC) and total sulphur (TS) were analysed using the ELTRA S/C Element Analyser. TOC was determined after sample de-carbonization by concentrated phosphoric acid. Total inorganic carbon (TIC) was calculated by the difference between TC and TOC. Based on TIC, the calcite equivalent was calculated as TIC 8.333 , where 8.333 is the stoichiometric calculation factor for $\mathrm{CaCO}_{3}$. All results are given in weight percent (wt.\%).

Rock-Eval pyrolysis was used to assess the source rock potential, prevailing kerogen type and thermal maturity (Espitalié et al., 1977; Lafargue et al., 1998; Behar et al., 2001). Free hydrocarbon content $S_{1}$ [mg HC/g rock], residual hydrocarbon potential $S_{2}\left[\mathrm{mg} \mathrm{HC} / \mathrm{g}\right.$ rock] and temperature of maximum of $S_{2}$ peak $T_{\max }\left[{ }^{\circ} \mathrm{C}\right]$ were determined using the Rock-Eval 6 instrument (Institut Français du Pétrole). The petroleum potential (PP) is represented by $S_{1}+S_{2}$ values [mg HC/g rock], the production in$\operatorname{dex}(\mathrm{PI})$ was calculated as $\mathrm{S}_{1} /\left(\mathrm{S}_{1}+\mathrm{S}_{2}\right)$ (Lafargue et al., 1998) and the hydrogen index $(\mathrm{HI})$ as $100 \cdot \mathrm{S}_{2} / \mathrm{TOC}(\mathrm{mg} \mathrm{HC} / \mathrm{g} \mathrm{TOC})$.

An Olympus BX51 microscope with a Zeiss Photomultiplier $M K 3$ system and fluorescence was used to measure the random reflectance with oil immersion and a lens with 40x magnification. The evaluation was carried out in accordance with the ISO 7404 standard. Random reflectance values were determined from particulate polished sections by SpectraVision software calibrated by spinel $(R=0.422 \%)$ and sapphire $(R=$ $0.596 \%)$ standards. The maceral composition was determined using the same equipment according to ICCP $(1998,2001)$.

\section{RESULTS}

The gamma logging records of the Menilite Formation intervals from the selected boreholes were correlated and the best fit distinguished (Fig. 4). As the result, the reconstructed depth was established. In this arrangement the cores of the Nevojice-1 and Mouchnice-2 boreholes were correlated with the Mouchnice-1 borehole profile as analogous sequences (Fig. 4). As a consequence, the expected sequence of the Menilite Formation in the area was restored (Fig. 5).

The Křepice- 5 borehole gamma log of the Menilite Formation, including its stratigraphic description (Stráník, 1979; Stráník et al., 1981), was attached for more detailed subdivision of the Menilite Formation (Fig. 4). Based on this, the previous indications of all studied cores according to the sample character belong to the Šitborice Member was confirmed. Moreover, the NP24 zone was demonstrated by the presence of Helicosphaera recta in the lowermost Mouchnice-1 (Core $\mathrm{No}^{\circ} 7$ ). However, the lowermost part of NP25 cannot be excluded within the uppermost part of the succession.

\section{BULK GEOCHEMICAL DATA}

The lithology of all cores is composed predominantly of non-calcareous dark grey silty shales with laminae of siltstone. A marly layer has been distinguished within the Mouchnice-1 (Core $\mathrm{No}^{\circ} 7$ ) with the calcite equivalent of $52 \mathrm{wt}$ \% (TIC of 6.2 wt.\%). The average value of calcite equivalent excluding this single sample with the maximum value reaches only $3.6 \mathrm{wt} . \%$ which represents a TIC content of $<0.5 \mathrm{wt} . \%$.

TOC and Rock-Eval pyrolysis data were used for the primary assessment of the source rock potential and determination of the predominant type of organic matter. TOC ranges from 0.63 to 6.9 wt. \%, with the average of 2.9 wt.\% (Fig. 5; Table 1). TOC values vary widely and do not show a significant correlation with the TIC. The highest values of TOC were determined on the Mouchnice-1 (Core No ${ }^{\circ} 7$ ) samples (from 2.1 to 6.9 wt. \%) and Mouchnice-2 samples (from 0.63 to 6.6 wt.\%). The Šitbořice Member evaluated has higher TOC in a wider range as compared to the stratigraphical analogues of the Aus-

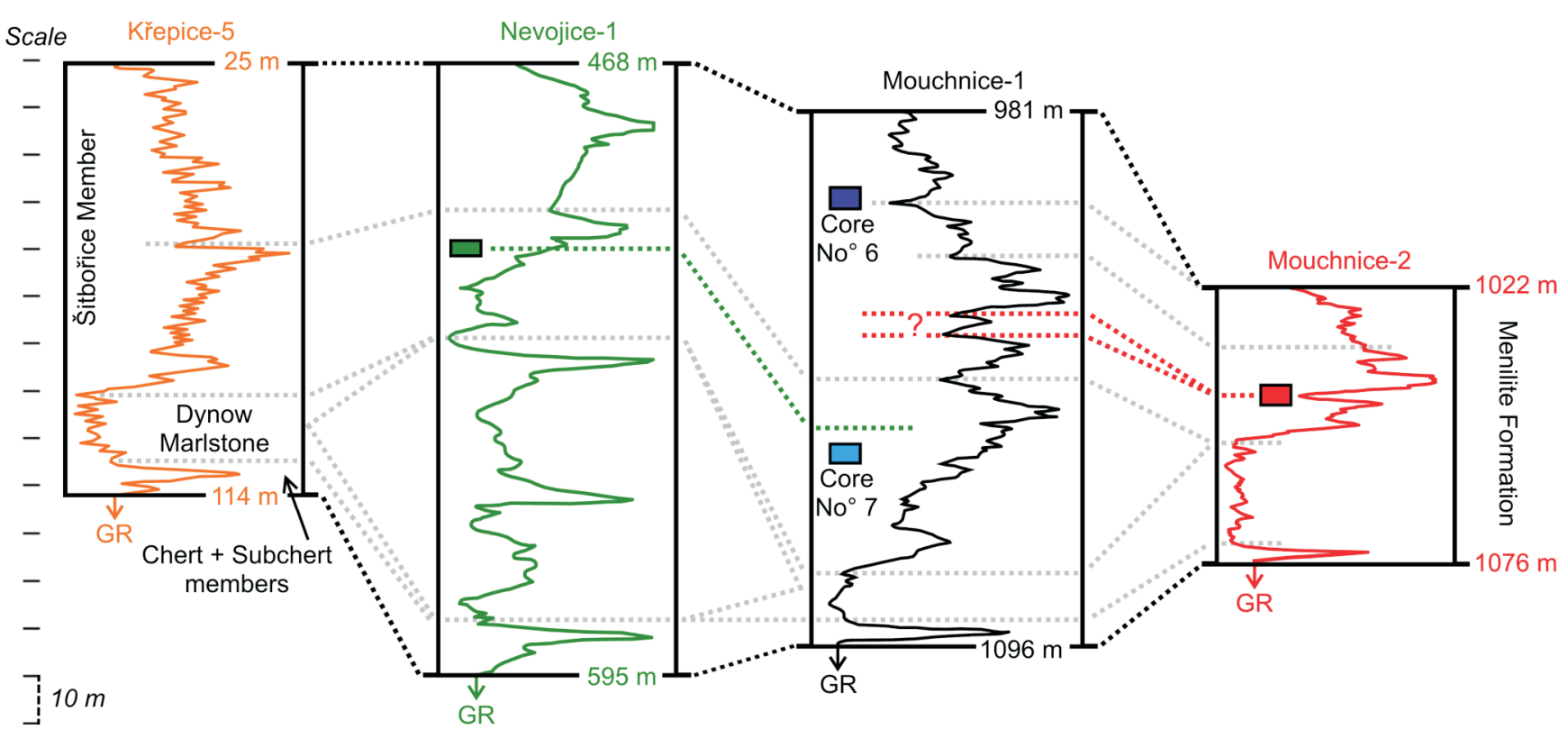

Fig. 4. Final gamma log correlation of the Menilite Formation from boreholes Nevojice-1, Mouchnice-1 and Mouchnice-2

The Křepice- 5 borehole gamma log including its stratigraphic description (Stráník, 1979; Stráník et al., 1981) is attached for more detailed subdivision of the formation; cores from Nevojice-1 and Mouchnice-2 boreholes (symbolized as coloured rectangles) were correlated to the profile of Mouchnice- 1 as an analogousical sequences 


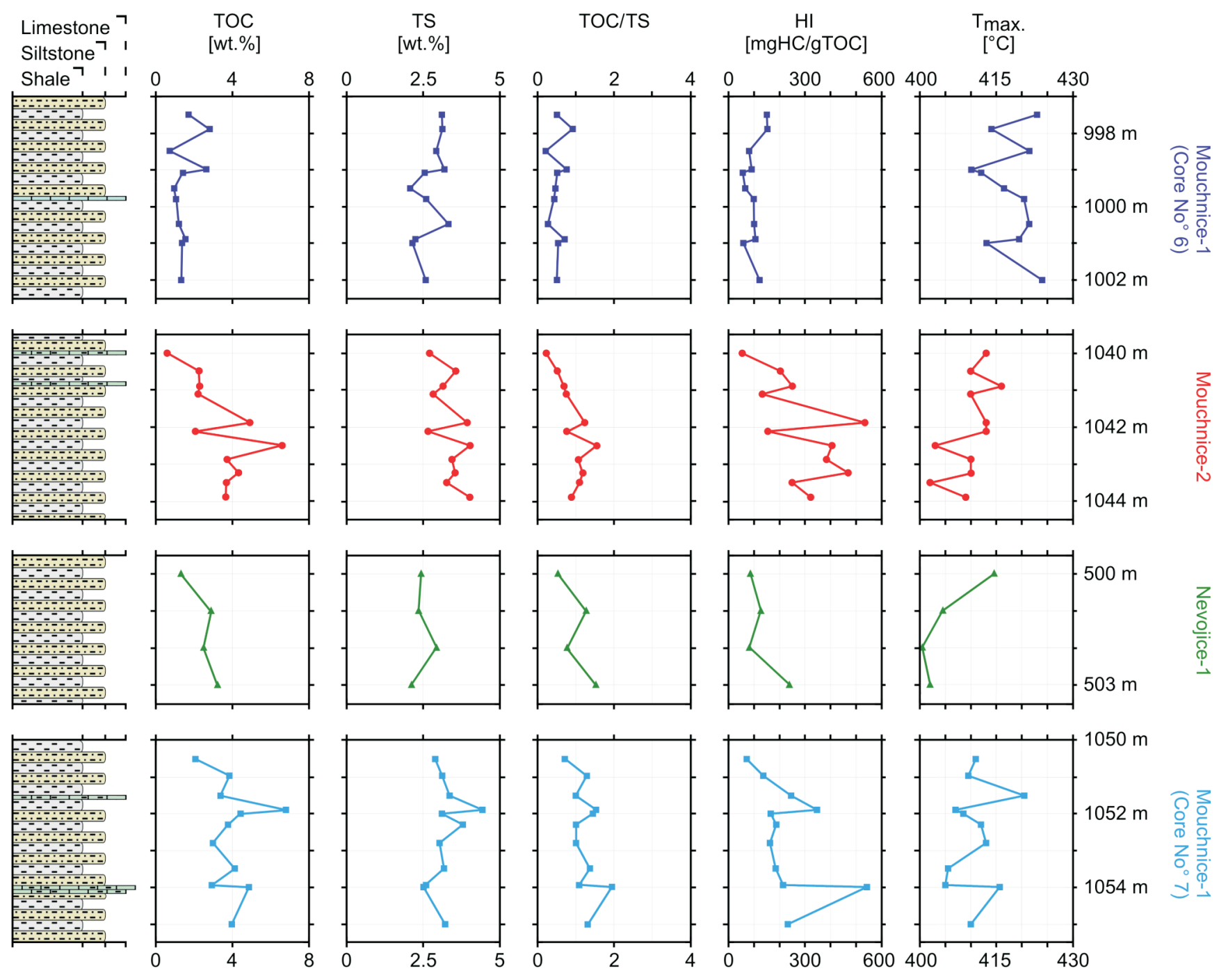

Fig. 5. Chart selection of results sorted according to the real depth of the Šitboriice Member

Schematic lithology; TOC - total organic carbon; TS - total sulphur; $\mathrm{HI}$ - hydrogen index; $T_{\max }$ - temperature of maximum of $\mathrm{S}_{2}$ peak

trian Molasse Basin and Waschberg Zone (Schmidt and Erdogan, 1996; Sachsenhofer et al., 2010; Gusterhuber et al., 2013; Pupp et al., 2018).

The total sulphur content of the samples studied ranges from 2.1 to $4.4 \mathrm{wt} . \%$ and does not show a single trend. The average content is equal to $3.0 \mathrm{wt} . \%$. The TOC/TS ratio was used as the environmental indicator. Values around 2.8 are typical of normal marine conditions. In contrast, values $>2.8$ are believed to indicate brackish conditions, whereas a significantly lower TOC/TS ratio possibly reflects sulphate reduction (Berner, 1984; Berner and Raiswell, 1984). In the case of euxinic bottom water conditions, bacterial sulphate reduction occurs both in the water column and in the sediments (Raiswell and Berner, 1985). The TOC/TS ratio of the cores studied reaches an average of 0.93 with the highest value of 1.95. The TOC/TS has a slightly decreasing upwards trend (Fig. 5) as clearly evident on samples from the Mouchnice-2 borehole and both cores of the Mouchnice-1 borehole which start and terminate the restored succession. Samples from the uppermost Mouchnice-1 (Core $\mathrm{No}^{\circ}$ 6) reach an average
TOC/TS value of 0.57 , while those of the lowermost cored sequence of Mouchnice-1 (Core $\mathrm{No}^{\circ} 7$ ) reach 1.24. Samples from other cores reach values of nearly 1 .

\section{ROCK-EVAL PYROLYSIS}

The $\mathrm{HI}$ ranges from 53 to $541 \mathrm{mg} \mathrm{HC} / \mathrm{g}$ TOC (with an average of 196 and median of $153 \mathrm{mg} \mathrm{HC} / \mathrm{g}$ TOC). The HI distribution (Fig. 6) has a random character in the Mouchnice-1 (Core $\mathrm{No}^{\circ} 7$ ) and Mouchnice-2 samples, but shows a narrow range in the Nevojice- 1 samples (from 85 to $238 \mathrm{mg} \mathrm{HC} / \mathrm{g} \mathrm{TOC}$ ) and especially in the Mouchnice-1 (Core $\mathrm{No}^{\circ} 6$ ) samples (from 55 to $151 \mathrm{mg} \mathrm{HC} / \mathrm{g} \mathrm{TOC}$ ). Lower HI values associated with the low TOC may suggest mineral matrix errors affecting the $\mathrm{HC}$ yields (Espitalié et al., 1980).

All samples studied reach a relatively narrow range of $T_{\max }$ values from 400 to $424^{\circ} \mathrm{C}$ indicating low thermal maturity and the presence of a large portion of unconverted original organic matter. This pattern is reflected in the kerogen type determina- 
tion and the evaluation of its source rock potential. Organic matter type determined based on the $\mathrm{HI}$ and $T_{\max }$ (Espitalié et al., 1985) indicates a comparable distribution between genetic components related to kerogen type II and III (Fig. 6).

In the case of a very narrow $T_{\max }$ interval, additional data are needed to interpret the depositional environment. The samples with high $\mathrm{HI}$ values (kerogen type II in Fig. 6) have a significantly higher TOC/TS ratio ranging from 0.64 to 1.95 (average 1.2). By contrast, samples that according to the Rock-Eval pyrolysis data belong to kerogen type III have TOC/TS from 0.23 to 1.24 (average 0.7) (Table 1).

The free hydrocarbons content ranges from 0.02 to $0.82 \mathrm{mg}$ $\mathrm{HC} / \mathrm{g}$ rock, while the residual hydrocarbon potential ranges between 0.34 to $26.9 \mathrm{mg} \mathrm{HC} / \mathrm{g}$ rock (Table 1). The petroleum potential varies between 0.36 to $27.7 \mathrm{mg} \mathrm{HC} / \mathrm{g}$ rock with an average of $7.4 \mathrm{mg} \mathrm{HC} / \mathrm{g}$ rock. Samples of Mouchnice-1 (Core No ${ }^{\circ} 7$ ) and Mouchnice-2 reach higher values in all parameters of free hydrocarbons content, residual hydrocarbon potential and petroleum potential with average petroleum potentials of 10.01 or $11.8 \mathrm{mg} \mathrm{HC} / \mathrm{g}$ rock, respectively. The production index values vary between 0.02 and 0.06 with an average of 0.03 (Fig. 7).

\section{ORGANIC PETROGRAPHY}

The organic matter occurring in the samples analysed consists of macerals of the liptinite group with admixtures of the vitrinite group. All the material studied is fairly homogeneous (Fig. 8), both lithologically and with respect to its maceral composition. The precise classification of the organic particles was limited due to the extremely fine-grained nature of all samples studied. The dominant macerals are alginite accompanied by sporadic cutinite, sporinite and bituminite. This maceral composition does not agree with Rock-Eval data.

The alginite consists mainly of lamalginite (Fig. 8), derived from small, unicellular or thin-walled colonial planktonic or benthic algae, with a distinctive lamellar form without recognizable structure. The translucency of the lamalginite is high.

The vitrinite macerals are present in low amounts and their size varies between 5 and $30 \mu \mathrm{m}$. Vitrinite reflectance measurement was difficult due to the small size of the particles and their very close association with pyrite. The random vitrinite reflectance $\left(R_{r}\right)$ was measured on vitrinite particles $(\mathrm{n}=30)$ and ranges from 0.24 to $0.31 \%$.

\section{DISCUSSION}

\section{SOURCE ROCK POTENTIAL}

The cross-plot showing the relationship of petroleum potential versus TOC demonstrates the high variability of the source rock potential and of the quality of the source rock. Based on screening results of this study (Fig. 9) the Šitbořice Member samples are mostly classified as "very good" (26 of 37 samples) source rock according to TOC and variable, mostly "poor" (14 samples) to "good" (12 samples) according to the petroleum potential. However, the average petroleum potential of $7.4 \mathrm{mg}$ $\mathrm{HC} / \mathrm{g}$ rock indicates a "good" source rock potential.

The different source rock potential estimation is at least partly caused by inert organic carbon within the TOC. A com-

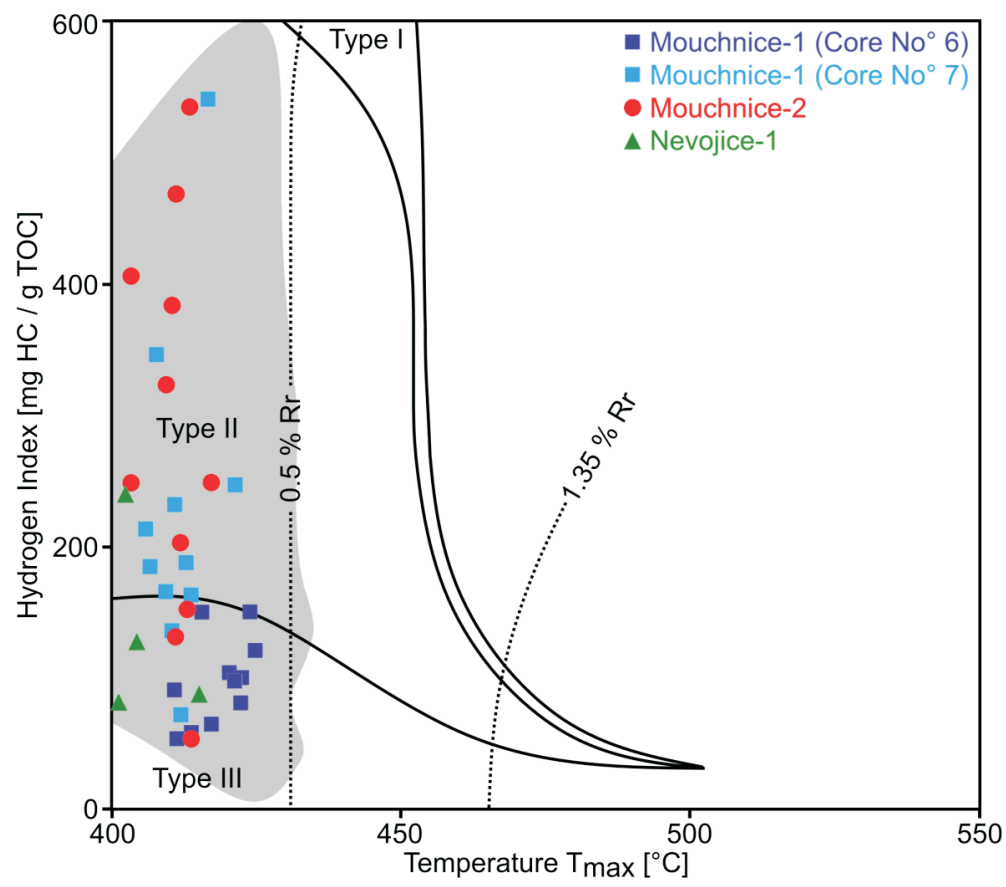

Fig. 6. Cross-plot of hydrogen index versus temperature $T_{\max }$ classified the kerogen type and thermal maturity of the rock and prevailing source potential

Maturation paths for kerogen according to Espitalié et al. (1985); archival data of the stratigraphical analogues of the Šitbořice Member (shaded area) are according to Sachsenhofer et al. (2010) and Pupp et al. (2018) 

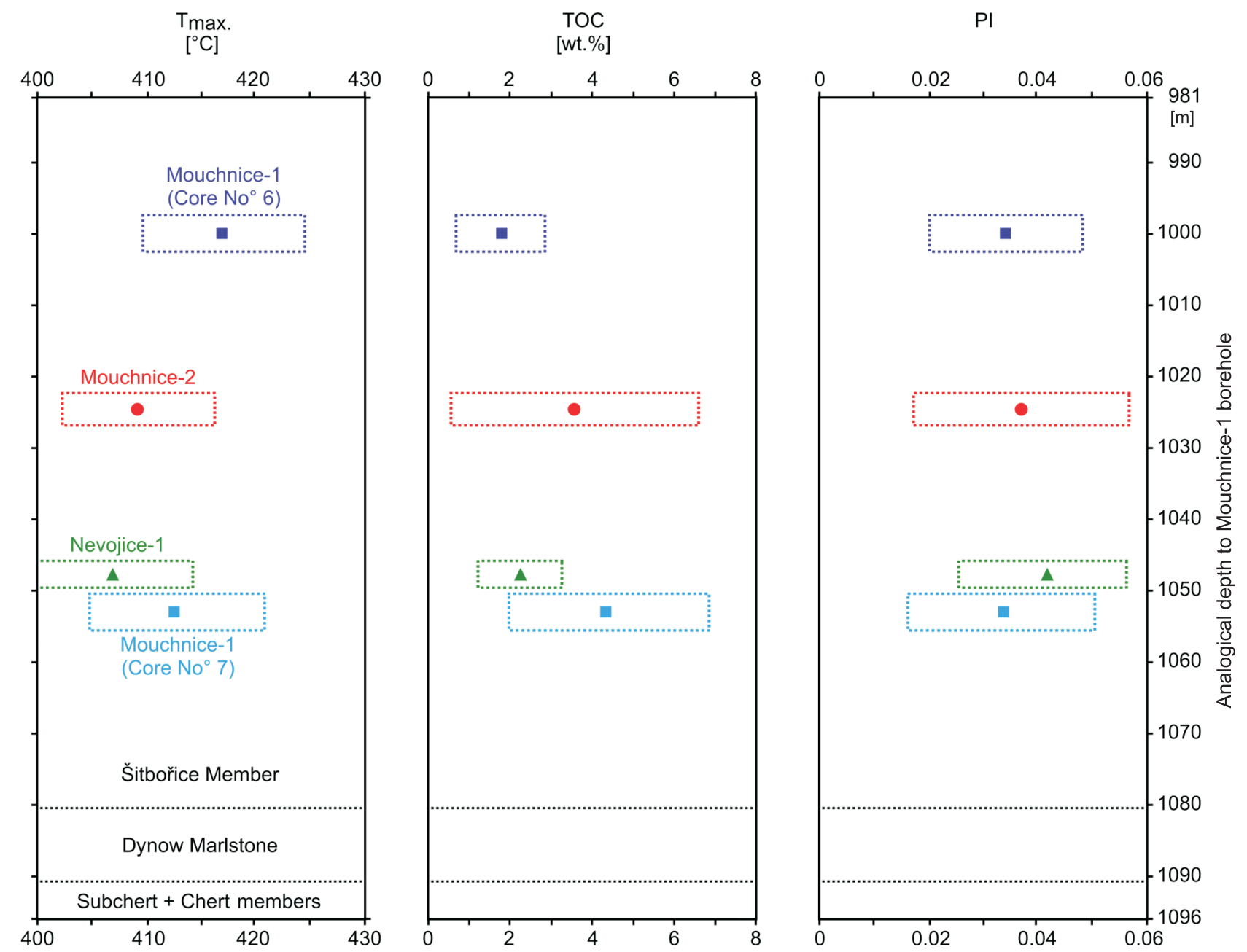

Fig. 7. Chart selection of results sorted according to analogous depth of the Menilite Formation in the Mouchnice-1 borehole indicating the quality of the source rock

$T_{\max }$ - temperature of maximum of $\mathrm{S}_{2}$ peak; TOC - total organic carbon; $\mathrm{PI}$ - production index

prehensive insight can be gained by applying a method suggested by Dahl et al. (2004) who presented a study on Rock-Eval pyrolysis performance on samples of variable lithology and organic matter content. A more precise source rock potential and kerogen type classification can be determined by "live" TOC calculated when the inert organic carbon is subtracted from the TOC. The amount of the inert organic carbon was estimated from the TOC versus $\mathrm{S}_{2}$ cross-plot (Fig. 10) and reaches 1.67 wt.\% for the Šitbořice Member evaluated. Based on this, the average "live" TOC reaches only $1.23 \mathrm{wt} . \%$ (not $2.9 \mathrm{wt} . \%$ ) suggesting mostly a "good" source rock potential which is in accordance with the average petroleum potential evaluated based on $S_{1}$ and $S_{2}$ values.

\section{KEROGEN TYPE AND DEPOSITIONAL ENVIRONMENT}

There are many studies demonstrating the significance and credibility of Rock-Eval pyrolysis for kerogen genetic type evaluation (e.g., Arfaoui et al., 2007; Aderoju and Bend, 2013; Ramachandran, 2013; Nady et al., 2015). However, the Rock-Eval method itself is often over-interpreted. The influence of low thermal maturity, lithology or TOC concentration on the resulting values has been well-documented (e.g., Katz, 1983; Peters, 1986; Dembicki, 1992; Dahl et al., 2004; Geršlová et al., 2015; Hazra et al., 2017). Therefore, it is advisable to always use supportive independent analysis such as maceral analysis, kerogen elemental data or biomarkers to demonstrate the kerogen type especially in the case of low-TOC sections (Delarue et al., 2013; Carvajal and Gentzis, 2015).

A comparable distribution of kerogen type II and III has been indicated by $\mathrm{HI}$ values (Fig. 6) in the Šitbořice Member evaluated, the same as in its stratigraphical analogues (Sachsenhofer et al., 2010; Pupp et al., 2018). However, a detailed examination of the selected samples demonstrated the dominant role of the alginite macerals from the liptinite group (Fig. 8) with admixtures of huminite from the vitrinite maceral group. The amount of terrigenous macerals was low. The dominant alginite would classify the kerogen as type I, but the presence of varying amounts of spores and pollen together with plant particles suggests rather the presence of kerogen type II. No significant differences between the individual samples present was found in terms of lithology and maceral composition. For this reason, it seems highly unlikely that the difference between the $\mathrm{HI}$ values 

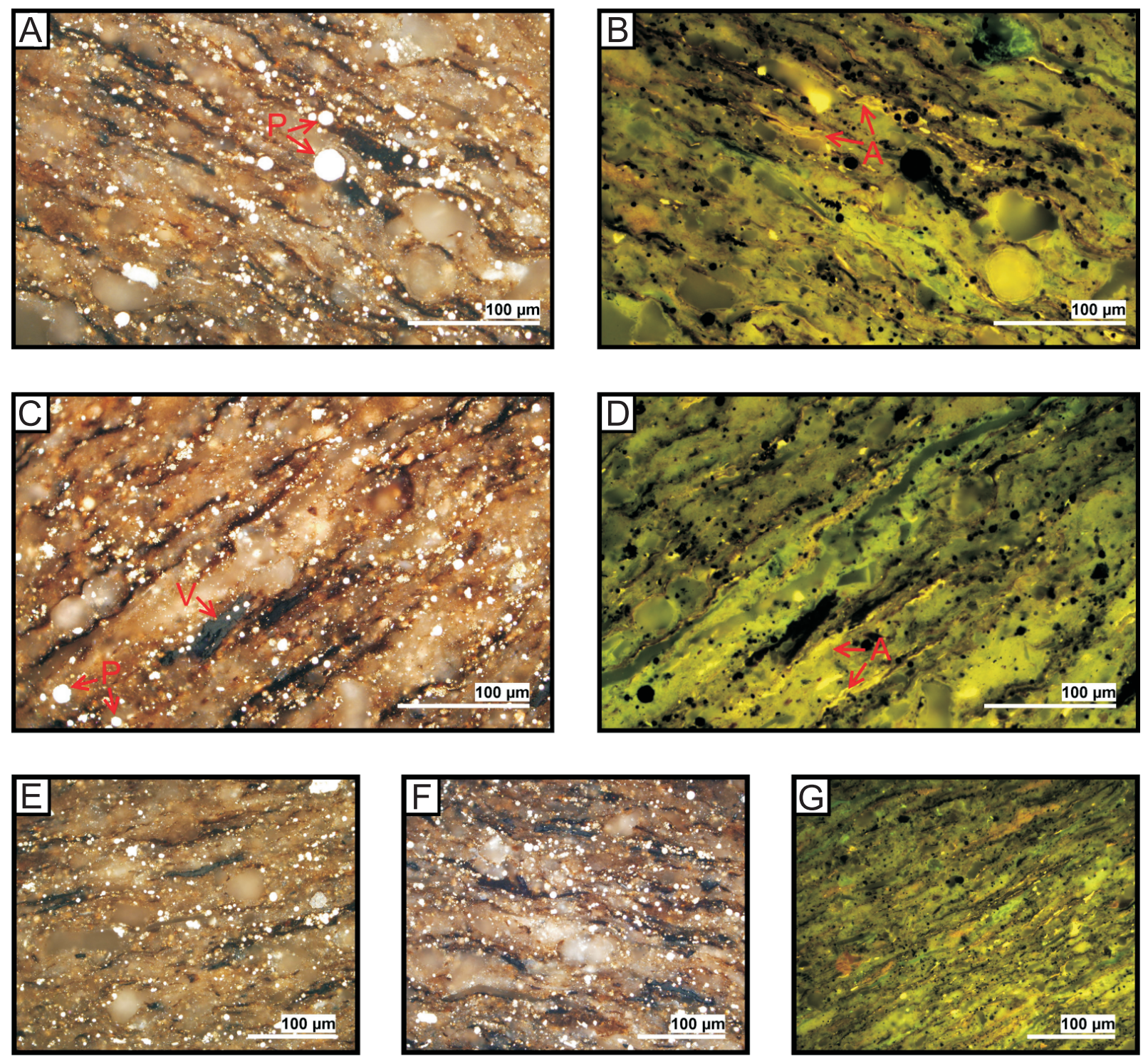

Fig. 8A-D - detailed characterization of the organic matter in the mineral ground-mass with dispersed fine pyrite framboids [Mouchnice-1 (Core $\mathrm{No}^{\circ}$ 7), $1051.5 \mathrm{~m}$ ]; the same area shown in polarized light (A and $\mathrm{C}$ ) and fluorescent light (B and D): V - vitrinite particle, A - alginite, $\mathrm{P}$ - pyrite; E, F - selection of samples from Mouchnice-1 (Core No $\left.{ }^{\circ} 6\right)(997.9$ $\mathrm{m})$, Mouchnice-2 $(1043.2 \mathrm{~m})$ and Nevojice-1 $(501 \mathrm{~m})$ in polarized (E and F) or fluorescence (G) light indicating the lithological homogeneity and comparable maceral composition of all samples studied

is due to a different kerogen type. The samples studied are lithologically comparable and the differences in $\mathrm{HI}$ cannot be due to different behaviour of the matrix during pyrolysis, as reported by Dembicki (1992).

The average $\mathrm{HI}$ calculated based on the "live" TOC reaches $452 \mathrm{mg} \mathrm{HC} / \mathrm{g}$ TOC and suggests the presence of kerogen type II, which is in accordance with the organic petrography observations and the relationship of residual hydrocarbon potential versus TOC (Fig. 10). Moreover, the trend as shown in Figure 10 reflects the stratigraphical position of the samples where the less mature samples of Mouchnice-1 (Core $\mathrm{No}^{\circ} 6$ ) from the top of the sequence are positioned bottom left.

Generally, oxygen-restricted conditions or a dysoxic environment can be expected based on the TOC versus TS relationship within the evaluated Šitborice Member (Fig. 11), the same as in the stratigraphical analogues of the Austrian Molasse Basin and Waschberg Zone (Sachsenhofer et al.,
2010; Pupp et al., 2018). Note that post-depositional processes which may cause pyrite framboids and the diagenetic degradation of organic matter may also lead to underestimation of the TOC/TS ratio.

\section{THERMAL MATURITY}

The thermal maturity of the organic matter is a very important parameter in terms of source rock potential because the hydrocarbons can be produced only under a favourable thermal regime (Tissot and Welte, 1984). The thermal maturity was indicated by Rock-Eval $\mathrm{PI}$ and $T_{\max }$ temperature supported by vitrinite $R_{r}$ (Table 1).

Both the Rock-Eval $T_{\max }$ (from 400 to $424^{\circ} \mathrm{C}$ ) and PI values (from 0.02 to 0.06 ) indicate the immaturity of organic matter compared to the stratigraphical analogues of the Austrian 


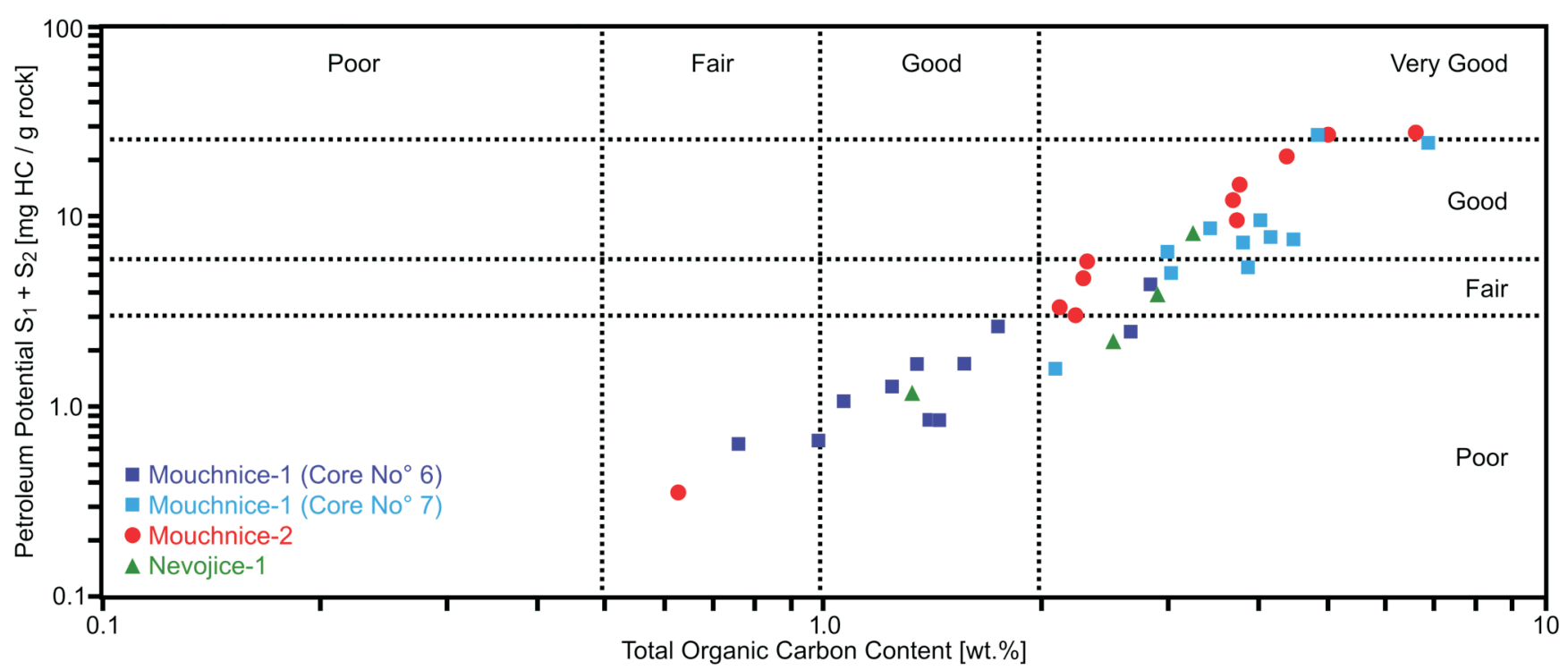

Fig. 9. Cross-plot of petroleum potential versus TOC indicating the quality of the source rock

Modified according to Peters (1986)

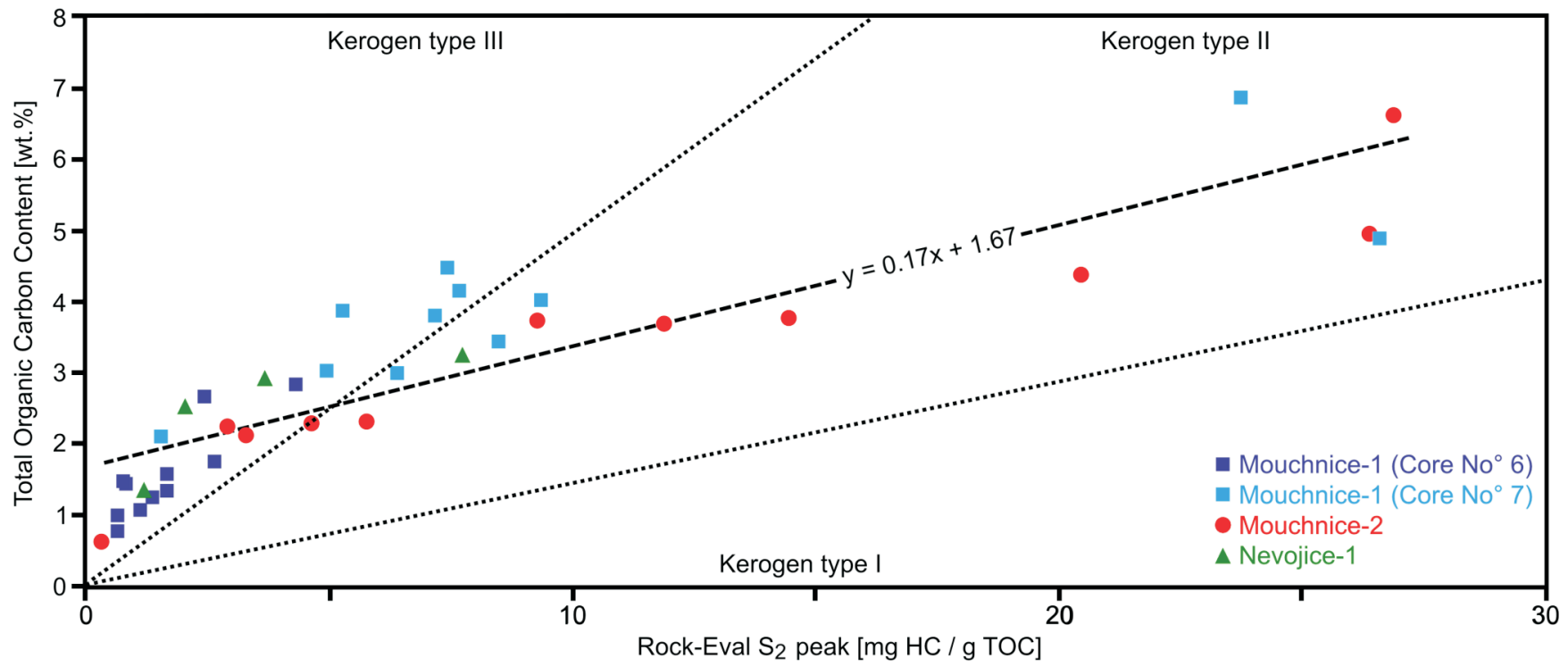

Fig. 10. Cross-plot of residual hydrocarbon potential (Rock-Eval $S_{2}$ peak) versus TOC revealing the amount of inert organic carbon (regression line offset is $1.67 \mathrm{wt} . \%$ )

Modified according to Dahl et al. (2004); genetic boundaries of kerogen types are according to Langford and Blanc-Valleron (1990)

Molasse Basin and Waschberg Zone (Sachsenhofer et al., 2010; Pupp et al., 2018). A thermal maturity comparable for all samples according to the Rock-Eval pyrolysis was supported by $R_{r}$ data (from 0.24 to $0.31 \% R_{r}$ ). The thermal immaturity indicates the presence of biological thermally labile organic matter that can release, during the laboratory measurements, more effluents as discussed above. Even though the Šitbořice Member studied has source rock potential, no significant amounts of hydrocarbons were generated because of the low thermal maturity.

\section{CONCLUSIONS}

The present study of organic matter from the Šitbořice Member of the Ždánice Unit represents the first comprehensive geochemical results from the Menilite Formation in the territory of the Czech Republic.

The source rock potential of the Šitborice Member is in this study classified mostly as "very good" according to TOC and variable, mostly "poor" to "good" according to the petroleum po- 


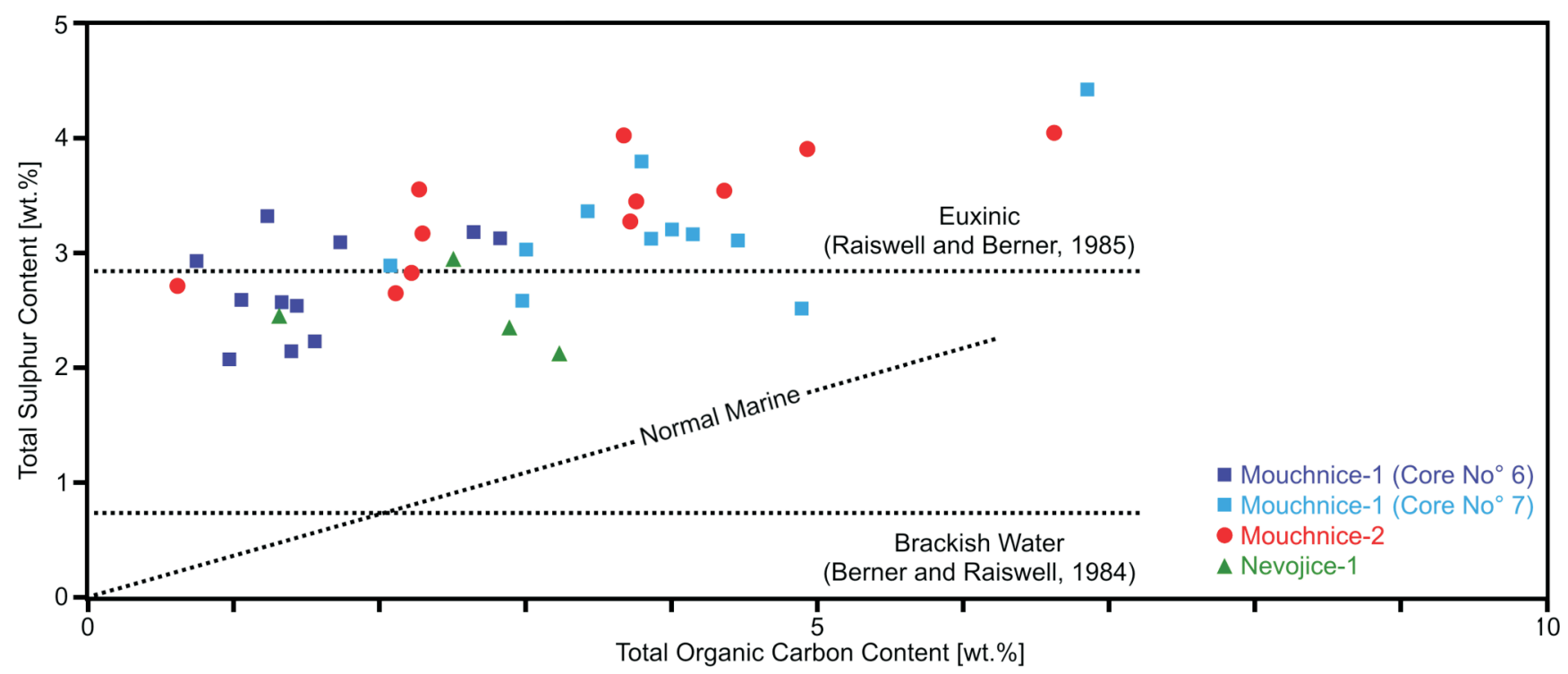

Fig. 11. Cross-plot of TOC versus TS indicating the oxygen-restricted conditions

Modified according to Berner and Raiswell (1984) and Raiswell and Berner (1985)

tential $\left(S_{1}+S_{2}\right)$. The average petroleum potential value assigned the Šitborice Member evaluated to "good" source rock which is in accordance with the TOC classification if the "live" TOC is used. However, the Šitborice Member within the area studied is immature based on both the random vitrinite reflectance and Rock-Eval data.

A comparable distribution between kerogen type II and III has been indicated by HI. Unlike it, the maceral composition does not agree with Rock-Eval data. The organic petrography observations show that the organic matter in the Šitborice Member belongs to the kerogen type II (kerogen type I is not excluded) with admixtures of variable amounts of kerogen type III. The organic petrography observations indicate that organic matter consists of alginite macerals from the liptinite group with admixtures of huminite from the vitrinite maceral group. All of the samples are fairly homogeneous both lithologically and with respect to the maceral composition. Moreover, both the relationship of residual hydrocarbon potential versus TOC (Dahl et al., 2004) and HI values calculated based on "live" organic carbon correspond to kerogen type II. These results are in agreement with the organic petrography.

Oxygen-restricted conditions or a dysoxic environment have been indicated by the TOC/TS ratio as a result of generally high sulphur contents (average of $3.0 \mathrm{wt} . \%$ ). The TOC/TS ratio has a slightly decreasing upwards trend. Samples from the uppermost Mouchnice-1 (Core $\mathrm{No}^{\circ}$ 6) reach an average $\mathrm{TOC} / \mathrm{TS}$ value of 0.57 , while those of the lowermost cored sequence of Mouchnice-1 (Core $\mathrm{No}^{\circ} 7$ ) reach 1.24.

Acknowledgements. All sampled core material analysed and discussed in this study originate from MND, a.s. Special thanks go to reviewers Y.V. Koltun, E. Bilkiewicz and P. Wójcik-Tabol for constructive remarks and comments which significantly improved on a previous version of the manuscript. The research has been financially supported by the institutional funds of Masaryk University.

\section{REFERENCES}

Aderoju, T.E., Bend, S.L., 2013. A Rock-Eval evaluation of the Bakken Formation in southern Saskatchewan. Summary of investigations 2013, 1. Saskatchewen Geological Survey, Saskatchewen Ministry of the Economy, Misc. Rep. 2013-4.1, Paper A-2.

Arfaoui, A., Montacer, M., Kamoun, F., Rigane, A., 2007. Comparative study between Rock-Eval pyrolysis and biomarkers parameters: a case study of Ypresian source rocks in central-northern Tunisia. Marine and Petroleum Geology, 24: 566-578.

Baldauf, J.G., Barron, J.A., 1990. Evolution of biosiliceous sedimentation patterns Eocene through Quaternary: paleoceano- graphic response to polar cooling. In: Geological History of the Polar Oceans: Arctic Versus Antarctic (eds. U. Bleil and J. Thiede): 575-607. Kluwer, Dordrecht.

Behar, F., Beaumont, V.B. de, Penteado, H.L., 2001. Rock-Eval 6 technology: performances and developments. Revue du l'Institute Français du Petrole, 56: 111-134.

Berggren, W.A., Kent, D.V., Swisher, C.C.III, Aubry, M.P., 1995. A revised Cenozoic geochronology and chronostratigraphy. SEPM Special Publication, 54: 129-212. 
Berner, R.A., 1984. Sedimentary pyrite formation: an update. Geochimica et Cosmochimica Acta, 48: 605-615.

Berner, R.A., Raiswell, R., 1984. C/S method for distinguishing freshwater from marine sedimentary rocks. Geology, 12: 365-368.

Brzobohatý, R., 1981. Fischreste aus den Menilit-Schichten der Zdanice-Einheit in Mahren (Oligozan, Aussere Westkarpaten) (in Czech with German summary). Zemní Plyn a Nafta, 26: $75-87$

Carvajal, H., Gentzis, O.T., 2015. Critical considerations when assessing hydrocarbon plays using Rock-Eval pyrolysis and organic petrology data: data quality revisited. International Journal of Coal Geology, 152: 113-122.

Chlupáč, I., Brzobohatý, R., Kovanda, J., Stráník, Z., 2002 Geologická minulost České republiky (in Czech). Academia Nakladatelství AV ČR, Praha.

Curtis, J.B., Kotarba, M.J., Lewan, M.D., Więcław, D., 2004 Oil/source rock correlations in the Polish Flysch Carpathians and Mesozoic basement and organic facies of the Oligocene Menilite Shales: insights from hydrous pyrolysis experiments. Organic Geochemistry, 35: 1573-1596.

Dahl, B., Bojesen-Koefoed, J., Holm, A., Justwan, H., Rasmussen, E., Thomsen, E., 2004. A new approach to interpreting Rock-Eval S2 and TOC data for kerogen quality assessment. Organic Geochemistry, 35: 1461-1477.

Delarue, F., Disnar, J.-R., Copard, Y., Gogo, S., Jacob, J., 2013. Can Rock-Eval pyrolysis assess the biogeochemical composition of organic matter during peatification? Organic Geochemistry, 61: 66-72.

Dembicki, H. Jr., 1992. The effects of the mineral matrix on the determination of kinetic parameters using modified Rock-Eval pyrolysis. Organic Geochemistry, 18: 531-539.

Dohnal, K., Drutarovský, Z., Hamršmíd, B., Holzknecht, M., Jandová, B., Kotásek, V., Polesňák, P., Šelle, M., Todt, L., Voborníková, J., Zádrapa, M., 1987. Závěrečná zpráva o vrtu Mouchnice-1 (in Czech). Internal report. MND k.p. Hodonín.

Espitalié, J., Laporte, J.L., Madec, M., Marquis, F., Leplat, P., Paulet, J., Boutefeu, A., 1977. Methode rapide de characterisation des roches meres, de leur potential petrolier et de leur degre d'evolution. Revue du l'Institute Français du Petrole, 32: 23-42.

Espitalié, J., Madec, M., Tissot, B., 1980. Role of mineral matrix in kerogen pyrolysis: influence on petroleum generation and migration. AAPG Bulletin, 64: 59-66.

Espitalié, J., Deroo, G., Marquis, F., 1985. La pyrolyse Rock-Eval et ses applications. Revue du l'Institut Français du Pétrole, 40: 563-579 and 755-784

Fuchs, R., Hamršmíd, B., Kuffner, T., Peschel, R., Rögl, F., Sauer, R., Schreiber, O., 2001. Mid-Oligocene Thomasl Formation (Waschberg Unit, Lower Austria) - micropaleontology and stratigraphic correlation. In: Paleogene of the Eastern Alps (eds. W.E. Piller and M.W. Rasser): 255-288. Verlag der Österreichischen Akademie der Wissenschaften, 14, Wien.

Geršlová, E., Opletal, V., Sýkorová, I., Sedláková, I., Geršl, M., 2015. A geochemical and petrographical characterization of organic matter in the Jurassic Mikulov Marls from the Czech Republic. International Journal of Coal Geology, 141-142: 42-50.

Glocker, E.F., 1844. Menilitschiefer in Mähren. Amtlicher Bericht über die Versamml deutscher Naturforscher und Aerzte in Graz, $139-141$.

Gregorová, R., 1988. The ichthyofauna of the Menilitic Formation in the locality Litencice and its stratigraphic position (in Czech with English summary). Časopis moravského muzea $v$ Brně, Vědy prírodní, 73: 83-88.

Gusterhuber, J., Hinsch, R., Linze, H.G., Sachsenhofer, R.F., 2013. Hydrocarbon generation and migration from sub-thrust source rocks to foreland reservoirs: the Austrian Molasse Basin. Austrian Journal of Earth Sciences, 106: 115-136.

Hazra, B., Dutta, S., Kumar, S., 2017. TOC calculation of organic matter rich sediments using Rock-Eval pyrolysis: critical consid- eration and insights. International Journal of Coal Geology 169 106-115.

Hrubanová, J., Těžký, A., 1980. Křepice-5 (Karotážní zhodnocení vrtu) (in Czech). Internal report. Ústřední Ústav Geologický, Brno.

International Committee for Coal and Organic Petrology, 1998 The new vitrinite classification (ICCP system 1994). Fuel, 77: 349-358.

International Committee for Coal and Organic Petrology, 2001 The new inertinite classification (ICCP system 1994). Fuel, 80 459-471.

Katz, B.J., 1983. Limitations of "Rock-Eval" pyrolysis for typing organic matter. Organic Geochemistry, 4: 195-199.

Koltun, Y.V., 1992. Organic matter in Oligocene Menilite Formation rocks of the Ukrainian Carpathians: palaeoenvironment and geochemical evolution. Organic Geochemistry, 18: 423-430.

Koltun, Y., Espitalié, J., Kotarba, M.J., Roure, F., Ellouz, N., Kosakowski, P., 1998. Petroleum generation in the Ukrainian External Carpathians and the adjacent foreland. Journal of Petroleum Geology, 21: 265-288.

Kosakowski, P., 2013. 1D modelling of hydrocarbon generation and expulsion from Oligocene Menilite source rocks in the San and Stryi rivers region (Polish and Ukrainian Carpathians). Geological Quarterly, 57 (2): 307-324.

Kosakowski, P., Wiecław, D., Kotarba, M.J., 2009. Source rock characteristic of the selected flysch deposits in the transfrontier area of the Polish Outer Carpathians (in Polish with English summary). Geologia, 35: 155-190.

Kosakowski, P., Koltun, Y., Machowski, G., Poprawa, P., Papiernik, B., 2018. The geochemical characteristics of the Oligocene - Lower Miocene Menilite Formation in the Polish and Ukrainian Outer Carpathians: a review. Journal of Petroleum Geology, 41: 319-335.

Kotarba, M.J., Koltun, Y.V., 2006. The origin and habitat of hydrocarbons of the Polish and Ukrainian parts of the Carpathian Province. AAPG Memoir, 84: 395-442.

Kotarba, M.J., Więcław, D., Koltun, Y.V., Lewan, M.D., Marynowski, L., Dudok, I.V., 2005. Organic geochemical study and genetic correlations between the Oligocene Menilite source rocks and oil and natural gas from surface seepages and from deep accumulations in the Starunia area (Ukrainian Carpathians). In: Polish and Ukrainian geological survey in 2004-2005 years in Starunia at the area of finds of woolly rhinoceroses and other extinct vertebrates (ed. M.J. Kotarba): 125-146. Polish Geological Institute and "Geosphere", Warszawa-Kraków.

Kotarba, M.J., Wiecław, D., Koltun, Y.V., Kuśmierek, J., Marynowski, L., Dudok, I.V., 2007. Organic geochemical study and genetic correlation of natural gas, oil and Menilite source rocks in the San and Stryi rivers region (Polish and Ukrainian Carpathians). Organic Geochemistry, 38: 1431-1456.

Kotarba, M.J., Wiecław, D., Dziadzio, P., Kowalski, A., Bilkiewicz, E., Kosakowski, P., 2013. Organic geochemical study of source rocks and natural gas and their genetic correlation in the central part of the Polish Outer Carpathians. Marine and Petroleum Geology, 45: 106-120.

Kotarba, M.J., Więcław, D., Dziadzio, P., Kowalski, A., Kosakowski, P., Bilkiewicz, E., 2014. Organic geochemical study of source rocks and natural gas and their genetic correlation in the eastern part of the Polish Outer Carpathians and Palaeozoic-Mesozoic basement. Marine and Petroleum Geology, 56: 97-122.

Kotarba, M.J., Więcław, D., Bilkiewicz, E., Dziadzio, P., Kowalski, A., 2017. Genetic correlation of source rocks and natural gas in the Polish Outer Carpathians and Paleozoic-Mesozoic basement east of Kraków (southern Poland). Geological Quarterly, 61 (4): 795-824.

Kowalska, K., Nowak, J., Zarzycki, M., 1988. Dokumentacja badań geofizycznych w otworze Mouchnice-2 (in Polish). Internal report. Polskie Górnictwo Naftowe i Gazownictwo. 
Köster, J., Kotarba, M.J., Lafargue, E., Kosakowski, P., 1998a Source rock habitat and hydrocarbon potential of Oligocene Menilite Formation (Flysch Carpathians, SE Poland). An organic geochemical and isotope approach. Organic Geochemistry, 29: 543-558.

Köster, J., Rospondek, M., Schouten, S., Kotarba, M.J., Zubrzycki, A., Sinninghe Damste, J.S., 1998b. Biomarker geochemistry of a foreland basin: Oligocene Menilite Formation in the Flysch Carpathians of Southeast Poland. Organic Geochemistry, 29: 649-669.

Krejčí, J., Holzknecht, M., Šelle, M., Zádrapa, M., 1989. Závěrečná zpráva o vrtu Nevojice-1 (in Czech). Internal report. MND k.p. Hodonín.

Krejčí, J., Hamršmíd, B., Holzknecht, M., Hudec, P., Jandová, B., Kowalska, K., Mietka, B., Nowak, J., Voborníková, J., Zarycki, M., 1991. Závěrečná zpráva o vrtu Mouhcnice-2 (in Czech. Internal report. MND s.p. Hodonín.

Krhovský, J., 1981. Stratigraphy and palaeoecology of the Menilite Formation of the Ždánice Unit and of the diatomites of the Pouzdřany Unit (the Western Carpathians, Czechoslovakia) (in Czech with English summary). Zemní Plyn a Nafta, 26: 45-62.

Krhovský, J., Djurasinović, M., 1993. The nannofossil chalk layers in the Early Oligocene Štibořice Member in Velké Němčice (the Menilitic Formation, Ždánice Unit, South Moravia): orbitally forced changes in paleoproductivity (in Czech with English summary). Zemní Plyn a Nafta, 15: 33-53.

Krhovský, J., Adamová, M., Hladiková, J., Maslowska, H., 1992. Paleoenviromental changes across the Eocene/Oligocene boundary in the Ždánice and Pouzdřany units (Western Carpathians, Czechoslovakia): the longterm trend and orbitally forced changes in calcareous nannofossil assemblages. Zemní Plyn a Nafta, 14b: 105-187.

Krhovský, J., Djurasinović, M., 1993. The nannofossil chalk layers in the Early Oligocene Štibořice Member in Velké Němčice (the Menilitic Formation, Ždánice Unit, South Moravia): orbitally forced changes in paleoproductivity (in Czech with English summary). Zemní Plyn a Nafta, 15: 33-53.

Krhovský, J., Rögl, F., Hamršmíd, B., 2001. Stratigraphic correlation of the Late Eocene to Early Miocene of the Waschberg Unit (Lower Austria) with the Ždánice and Pouzdřany Units (South Moravia). Schriftenreihe der Erdwissenschaftlichen Kommission, Österreichische Akademie der Wissenschaften, 14: 225-254.

Kruge, M.A., Mastalerz, M., Solecki, A., Stankiewicz, B.A., 1996. Organic geochemistry and petrology of oil source rocks, Carpathian Overthrust region, southeastern Poland - implications for petroleum generation. Organic Geochemistry, 24: 897-912.

Lafargue, E., Marquis, F., Pillot, D., 1998. Rock-Eval 6 applications in hydrocarbon exploration, production, and soil contamination studies. Revue de l'Institut Français du Pétrole, 53: 421-437.

Langford, F.F., Blanc-Valleron, M.M., 1990. Interpreting Rock-Eval pyrolysis data using graphs of pyrolizable hydrocarbons vs. total organic carbon. AAPG Bulletin, 74: 799-804.

Lewan, M.D., Kotarba, M.J., Curtis, J.B., Więcław, D., Kosakowski, P., 2006. Oil-generation kinetics for organic facies with Type-II and -IIS kerogen in the Menilite Shales of the Polish Carpathians. Geochimica et Cosmochimica Acta, 70: 3351-3368

Nady, M.M.El, Ramadan, F.S., Hammad, M.M., Lotfy, N.M., 2015 Evaluation of organic matters, hydrocarbon potential and thermal maturity of source rocks based on geochemical and statistical methods: case study of source rocks in Ras Gharib oilfield, central Gulf of Suez, Egypt. Egyptian Journal of Petroleum 24 203-211.

Peters, K.E., 1986. Guidelines for Evaluating Petroleum Source Rock Using Programmed Pyrolysis. AAPG Bulletin, 70: 318-329.
Pícha, F.J., Stráník, Z., 1999. Late Cretaceous to early Miocene deposits of the Carpathian foreland basin in southern Moravia. International Journal of Earth Sciences, 88: 475-495.

Pícha F.J., Stráník, Z., Krejčí, O., 2006. Geology and Hydrocarbon Resources of the Outer West Carpathians and their Foreland, Czech Republic. AAPG Memoir, 84: 49-175).

Prothero, D., Ivany, L., Nesbitt, E., 2000. The marine Eocene-Oligocene transition: Penrose Conference Report. GSA Today, 10: 10-11.

Pupp, M., Bechtel, A., Gratzer, R., Heinrich, M., Kozak, S., Lipiarski, P., Sachsenhofer, R.F., 2018. Depositional environment and petroleum potential of Oligocene rocks in the Waschberg Zone (Austria). Geologica Carpathica, 69: 410-436.

Raiswell, R., Berner, R.A., 1985. Pyrite formation in euxinic and semi-euxinic sediments. American Journal of Science, 285: 710-724.

Ramachandran, K., Babu, V., Behera, B.K., Harinarayana, T., 2013. Source rock analysis, thermal maturation and hydrocarbon generation using rock-eval pyrolysis in parts of Krishna-Godavari basin, India: a case study. Journal of Petroleum Exploration and Production Technology, 3: 11-20.

Rögl, F., 1998. Paratethys Oligocene-Miocene correlation. Abhandlungen der Senckenbergischen Naturforschenden Gesellschaft, 549: 3-7.

Rögl, F., Krhovský, J., Hamršmíd, B., Braunstein, R., Sauer, R., Seifert, P., 2001. The Ottenthal Formation revised - sedimentology, micropaleontology and stratigraphic correlation of the Oligocene Ottenthal sections (Waschberg Unit, Lower Austria). In: Paleogene of the Eastern Alps (eds. W.E. Piller and M.W. Rasser): 291-345. Verlag der Österreichischen Akademie der Wissenschaften, 14, Wien.

Sachsenhofer, R.F., Koltun, Y.V., 2012. Black shales in Ukraine - a review. Marine and Petroleum Geology, 31: 125-136.

Sachsenhofer, R.F., Schulz, H.M., 2006. Architecture of Lower Oligocene source rocks in the Alpine Foreland Basin: a model for syn- and post-depositional source-rock features in the Paratethyan realm. Petroleum Geoscience, 12: 363-377.

Sachsenhofer, R.F., Leitner, B., Linzer, H.G., Bechtel, A., Ćorić, S., Gratzer, R., Reischenbacher, D., Soliman, A., 2010. Deposition, erosion and hydrocarbon source potential of the Oligocene Eggerding Formation (Molasse Basin, Austria). Austrian Journal of Earth Sciences, 103: 76-99.

Sachsenhofer, R.F., Koltun, Y.V., 2012. Black shales in Ukraine - a review. Marine and Petroleum Geology, 31: 125-136.

Salamy, K.A., Zachos, J.C., 1999. Latest Eocene-early Oligocene climate change and Southern Ocean fertility: Inferences from sediment accumulation and stable isotope data. Palaeogeography Palaeoclimatology Palaeoecology, 145: 61-77.

Schmidt, F., Erdogan, L.T., 1996. Palaeohydrodynamics in exploration. EAGE Special Publication, 5: 255-265.

Schulz, H.M., Sachsenhofer, R.F., Bechtel, A., Polesny, H., Wagner, L., 2002. Origin of hydrocarbon source rocks in the Austrian Molasse Basin (Eocene-Oligocene transition). Marine and $\mathrm{Pe}-$ troleum Geology, 19: 683-709.

Schulz, H.M., Bechtel, A., Rainer, T., Sachsenhofer, R.F., Struck, U., 2004. Paleocenaography of the western Central Paratethys during nannoplankton zone NP 23: The Dynów Marlstone in the Austrian Molasse Basin. Geologica Carpathica, 55: 311-323.

Stráník, Z., 1979. Litologický profil vrtu Křepice-5 (in Czech). MS, Ústřední Ústav Geologický, Brno.

Stráník, Z., 1981. Lithofacies and correlation of the Menilitic Formation in the Carpathian Flysch belt of Moravia (in Czech with English summary). Zemní Plyn a Nafta, 26: 9-18.

Stráník, Z., Hanzlíková, E., 1968. Stratigraphy of the Magura Group of nappes. In: Regional Geology of Czechoslovakia, Part II - The West Carpathians (eds. M. Mahel and T. Buday): 446-480. Geological Survey of Czechoslovakia in Academia, Praha. 
Stráník, Z., Benešová, E., Cicha, I., Gabriel, M., Kolářová, M., Žůrková, I., 1974. Vysvětlující text k základní geologické mapě 1 : 25000 M-33-106-D-c (Šitbořice) (in Czech). MS, Ústřední Ústav Geologický, Brno.

Stráník, Z., Jurašová, F., Pešlová, H., 1981. Šitbořice Member in the borehole Krepice-5 (in Czech with English summary). Zemní Plyn a Nafta, 26: 701-710.

Šelle, M., 1987. Zhodnocení karotážního měření z vrtu Mouchnice-1 (in Czech). Internal report. Moravské naftové doly, k.p. Hodonín.

Šelle, M., 1988. Zhodnocení karotážního měření z vrtu Nevojice-1 (in Czech). Internal report. Moravské naftové doly, k.p. Hodonín.

Švábenická, L., Bubík, M., Stráník, Z., 2007. Biostratigraphy and palaeoenvironmental changes on the transition from the Menilite to Krosno lithofacies (Western Carpathians, Czech Republic). Geologica Carpathica, 58: 237-262.

ten Haven, H.L., Lafargue, E., Kotarba, M.J., 1993. Oil/oil and oil/source rock correlations in the Carpathian Foredeep and overthrust, south-east Poland. Organic Geochemistry, 20: 935-959.
Thomas, E., Zachos, J.C., Bralower, T.J., 2000. Deep-sea environments on a warm Earth: Latest Paleocene-early Eocene. In: Warm Climates in Earth History (eds. B.T. Huber, K.G. MacLeod and S.L. Wing): 132-160. Cambridge University Press, New York.

Tissot, B.P., Welte, D.H., 1984. Petroleum Formation and Occurrence. Springer-Verlag, Berlin, Heidelberg.

Wagner, L.R., 1996. Die tektonisch-stratigrafische Entwicklung der Molasse und deren Untergrundes in Oberösterreich und Salzburg. Österreichische Gemmologische Gesellschaft, Exkursionsführer, 16: 36-65.

Wagner, L.R., 1998. Tectono-stratigraphy and hydrocarbons in the Molasse Foredeep of Salzburg, Upper and lower Austria. Geological Society Special Publications, 134: 339-369.

Ziemianin, K., Brzuszek, P., Słoczyński, T., Jankowski, L., 2015 Dispersed organic matter in shales from Menilite Beds within Polish Outer Carpathians - preliminary diagnosis. Nafta-Gaz, 71: 616-623. 